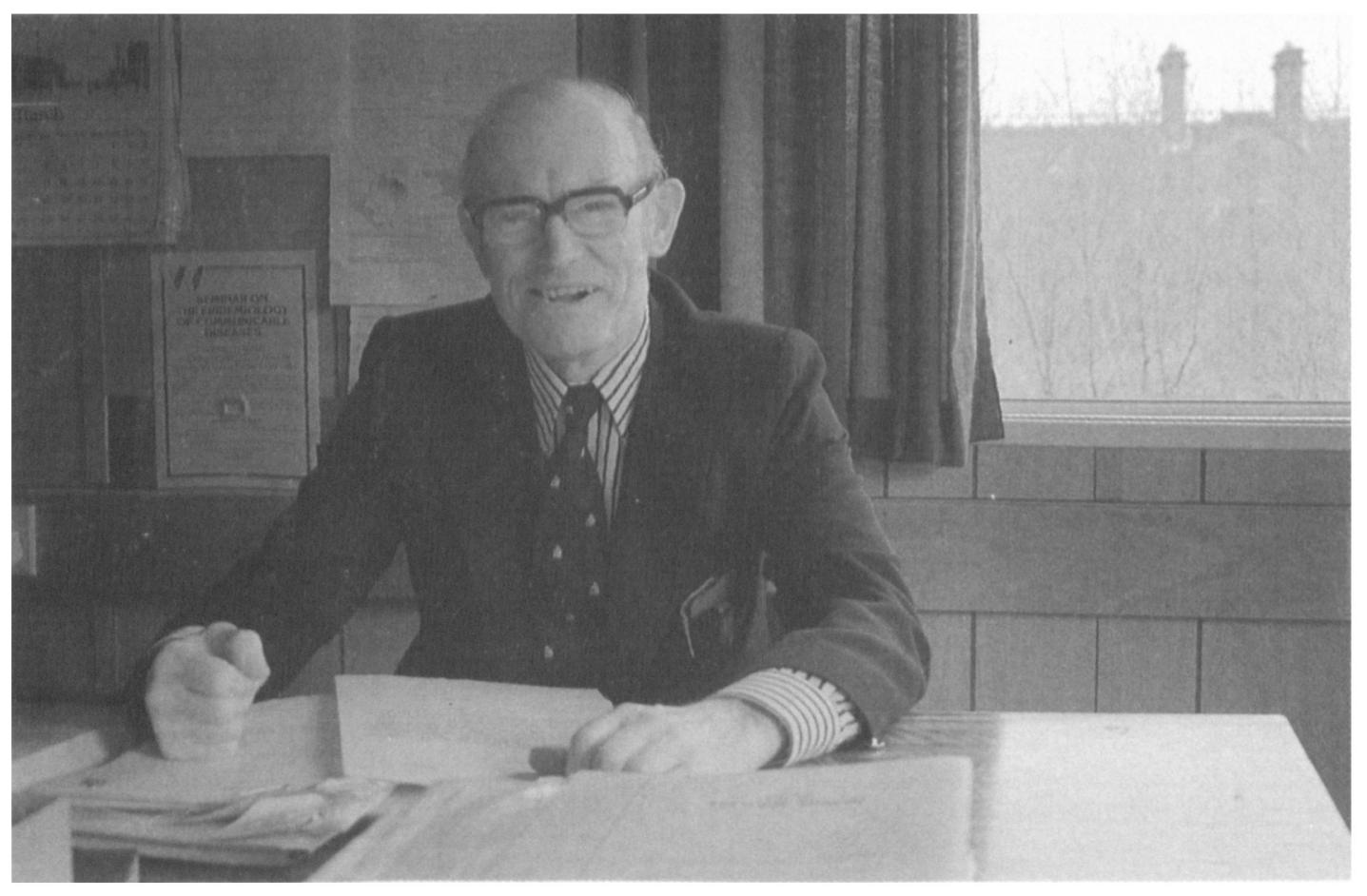




\section{A tribute to}

N. R. GRIST

Norman Roy Grist retired from his position as the second and, for the time being at least, last holder of the Chair of Infectious Disenses in the University of Glasgow at the end of September 1983, at which time he also relinquished the post of Director of the Regional Virus Laboratory at Ruchill Hospital, Glasgow. Through his teaching in the laboratory and in the Department of Infectious Diseases, through the internationally recognized course of diagnostic virology at Ruchill and through the publication of the book on diagnostic virology, written by him and his colleagues, he has had a profound influence on the standard of diagnostic clinical virology and has brought $a$ realistic approach to the discipline. In addition to his direct influence in the field of virology he has had an internationally recognized involvement in the field of epidemiology, and this brought him into contact with an even wider circle of colleagues. His colleagues inevitably became friends and it was felt appropriate by many of us who had benefit of contact with him that a tribute should be made to his pre-eminent position in the fields in which he has worked.

Born in Doncaster he came to Glasgow as a schoolboy and went on to study medicine at Glasgow University. He was already an accomplished pianist but decided that study for a diploma in music was inappropriate in a country at war that needed doctors. Hence after qualifying he went to war and saw service in North Africa and, from the D-day landings in Normandy, across Europe before taking up a career in infectious disenses.

He started work as a clinician and with Dr, later Professor, Tom Anderson's interest in pneumonia, became involved in clinical, epidemiological and then laboratory aspects of the problem. Subsequently, first at Knightswood Hospital and then at Ruchill, he developed his interest in virology. He worked for a time with Allan Downie at Liverpool and also with Fred MeCallum at the Virus Reference Laboratory at Colindale before visiting the United States, where he worked on influenza at Ann Arbor with the late Tom Francis Jnr. There he made many friends, both virologists and epidemiologists, with whom he kept up a close and fruitful contact. Mennwhile, the Regional Virus Laboratory at Ruchill, developed as a result of the poliomyelitis epidemics of the late 1940s and early 1950s, opened. On his return to Ruchill his work flourished and his reputation and that of the virus laboratory beeame known and respected internationally. Guest workers came from many oversens countries and from throughout the UK to spend a year in the Department as well as taking part in the course in diagnostic virology. NRG's interest in paralysis due to viruses other than poliovirus led to work with Coxsnckic viruses and to a deep interest in the renctions between viruses and the heart. His interest in epidemiology was stimulated by his teacher and predecessor in the Chair of Infectious Diseases, Tom Anderson. The interaction between Tom Anderson, NRG and Elias-Jones led to the formation, in 1967, of the Communicable 
Diseases (Scotland) Unit under the direction of Dan Reid, which is recognized as a prime example of a national surveillance centre. He maintained (and, happily continues to maintain) a close association with this unit, with which he co-opernted in organizing an annual seminar on the Epidemiology of Infectious Disenses. His aphorism 'finding out is fun' epitomizes his attitude to science. 'Thus, when a virus was postulated as the cause of leukacmin he stimulated work which eventually showed that the cultures contained a mycoplasma. When nude mice appeared as mutants in his animal house stock he sent them for genetic investigation. These mice, later found to be athymic, formed, and continue so to do, a basic tool for much fundamental research in immunology. His epidemiological interests (characterized by the meticulous study with Dan Reid of the outbreak of Legionnaires' disease in Benidorm, Spain, in 1973, for which both workers were honoured by the Spanish Government) brought him into a close and fruitful relationship with the WHO, which led to work with, and foreign travel for, this and other agencies. Another honour NRG received was a Bronze Medal awarded to him in 1972 by the University of Helsinki. One of the benefits of his international connexions has been the generous way in which he has involved colleagues and pupils, so that many of us have been able to gain experience on a wider stage than the United Kingdom alone and have been able to further pursue and extend these international relationships. Another and important aspect of epidemiology has been his ongoing study, on behalf of the Association of Clinical Pathologists, first of hepatitis and now of all infections in clinical laboratories in the UK. He is a meticulous bench-worker and his expertise on safety has been sought by many. Like Allan Downic, to whom tribute was paid in this Journal in 1982, NRG is a keen bird watcher and took delight in pointing out to staff and visitors alike that the kestrel which nested in the tower at Ruchill Hospital was not the only interesting and unusual bird to be seen in the grounds of the hospital. This deep interest in natural phenomena extended into all aspects of his professional and personal life. Even in the rural setting of his cottage on the Isle of Arran he has combined being an unpaid labourer with 'flagging' for ticks and producing beautiful photographs of the various forms he has discovered.

\section{Editorial note}

The Editors of the Journal of Hygiene were pleased to receive the following 12 papers, all of which have been processed through the usual referecing and editorial procedures. It is a tribute in itself that so many former collengues can produce simultaneously papers acceptable to an international journal. There are many more friends and colleagues who would have wished to have been able to contribute and NRG can rest assured that wherever he pursues his interests he will find a host (or should it be a flock?) of well-wishers. 